\title{
PENGARUH PENGETAHUAN PERATURAN PERPAJAKAN DAN KUALITAS PELAYANAN TERHADAP KEPATUHAN WAJIB PAJAK KPPP BANDUNG KAREES
}

\author{
Dwi Anggraeni Saputri ${ }^{1}$, Ela Sulistia ${ }^{2}$ \\ Fakultas Bisnis, Universitas Mitra Indonesia ${ }^{1}$ \\ Email: dwianggraenisaputri@umitra.ac.id ${ }^{1}$ \\ Sekolah Administrasi Bisnis dan Keuangan Program, Institut Manajemen Telkom² \\ Email: elasulistia@gmail.com ${ }^{2}$
}

\begin{abstract}
ABSTRAK
Kepatuhan wajib pajak salah satunya dapat dilihat dari jumlah wajib pajak dalam menyampaikan Surat Pemberitahuan (SPT), beberapa faktor yang mempengaruhi kepatuhan wajib pajak yaitu pengetahuan peraturan perpajakan yang dimiliki oleh wajib pajak serta kualitas pelayanan yang diberikan oleh aparat pajak.Tujuan dilakukannya penelitian ini adalah untuk mengetahui seberapa besar pengaruh pengetahuan peraturan perpajakan dan kualitas pelayanan terhadap kepatuhan wajib pajak baik secara parsial maupun secara simultan.

Penelitian ini merupakan penelitian deskriptif verifikatif bersifat kausalitas. Penelitian ini dilakukan di KPP Pratama Bandung Karees. Teknik sampel dilakukan adalah conveniance sampling dengan total sampel terdiri dari 100 orang wajib pajak orang pribadi, 22 orang dari Account Representative (AR), dan 11 orang dari pemeriksa pajak. Pengujian statistik yang digunakan adalah perhitungan korelasi pearson, uji asumsi klasik, koefisien determinasi, analisis regresi berganda, uji hipotesis dengan menggunakan aplikasi SPSS 17,0.

Hasil dari penelitian ini menunjukkan bahwa pengetahuan peraturan perpajakan dan kualitas pelayanan secara simultan berpengaruh signifikan terhadap kepatuhan wajib pajak dengan tingkat koefisien determinasi $19,3 \%$. Secara parsialpengetahuan peraturan perpajakanberpengaruh signifikan dengan arah negatif, sedangkan kualitas pelayanan tidak berpengaruh signifikan dengan arah negatif terhadap kepatuhan wajib pajak.
\end{abstract}

Kata Kunci: Pengetahuan Peraturan Perpajakan, Kualitas Pelayanan, Kepatuhan Wajib Pajak.

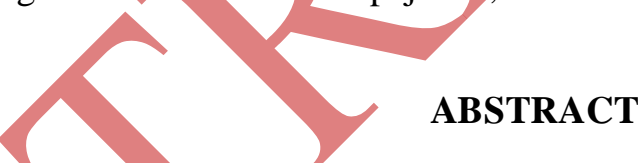

One oftaxpayer compliancecan be seenfrom thenumber of taxpayersin conveying(SPT), severalfactors thataffecttax complianceis tax regulationknowledgepossessedby the taxpayeras well as thequality of services providedby thetax authorities. The purposeof this study istodetermine how much influencethe tax regulation knowledgeandservice quality on tax complianceeither partiallyor simultaneously.

This study is averification descriptive research with causality characteristic. The research wasconductedin KPP Pratama BandungKarees. Sampling technique that conducted is conveniance sampling with sample total consisted of 100individual taxpayers, 22peoplefrom theAccount Representative $(A R)$, andllpeoplefrom thetax inspectors. The statistic test usedis thePearson correlationcalculations, the classical assumption, the coefficientof determination, multiple regression analysis, hypothesis testingusingSPSS17.0.

The results ofthis study indicatethatknowledgeof taxregulationandthe quality of servicesimultaneouslysignificant effect ontaxpayer compliancewiththe coefficient of determination $19.3 \%$ level. Partiallyknowledge oftax regulation effect significantlywiththe negativedirection, whereas there is no significant effect onthe quality of servicewitha negativedirectionon tax compliance.

Keywords: tax regulation knowledge, quality of service, taxpayer compliance 


\subsection{Latar Belakang Penelitian}

Pajak merupakan sumber utama penerimaan negara disamping penerimaan dari sumber migas dan non migas. Optimalisasi penerimaan pajak dikarenakan semakin meningkatnya kebutuhan dana pembangunan. Pajak bagi pemerintah tidak hanya merupakan sumber pendapatan, tetapi juga merupakan salah satu variabel kebijaksanaan yang digunakan untuk mengatur jalannya perekonomian. Dengan pajak pemerintah dapat mengatur alokasi sumber-sumber ekonomi, mengatur laju inflasi, dan sebagainya. Oleh karena itu pajak mempunyai fungsi strategis dalam suatu negara.

Menurut Surat Edaran Direktur Jenderal Pajak Nomor SE-45/PJ/2007 salah satu tujuan pokok reformasi administrasi perpajakan adalah peningkatan kualitas pelayanan kepada Wajib Pajak dan seluruh stakeholder perpajakan. Kualitas pelayanan itu sendiri yaitu pelayanan yang dapat memberikan kepuasan kepada pelanggan dan tetap dalam batas memenuhi standar pelayanan yang dapat dipertanggungjawabkan serta harus dilakukan secara terus-menerus.

Direktur Penyuluhan Pelayanan dan Hubungan Masyarakat Fatimah Azzahra mengatakan akan mengadakan sensus pajak. Menurut Fatimah, di Indonesia terdapat 20 juta orang Wajib Pajak Orang Pribadi yang telah memiliki Nomor Pokok Wajib Pajak (NPWP). Para Wajib Pajak Orang Pribadi yang melapor serta membayar pajak hanya sekitar 8,5 juta orang saja. Ditjen Pajak juga akan memberikan edukasi cara mengisi Surat Pemberitahuan (SPT) tahunan kepada para Wajib Pajak. (kompas.com, 25 September 2011).

Tidak dapat dipungkiri juga bahwa sebagian Wajib Pajak di Indonesia adalah orang-orang menengah ke atas yang berpenghasilan tinggi, berpendidikan tinggi dan seharusnya sudah memiliki pemahaman yang baik tetapi kepatuhan mereka untuk membayar pajak juga masih tergolong lemáh. (kompas.com, 30 September 2011).

Menurut Menteri Keuangan Agus Martowardojo, Wajib Pajak Orang Pribadi yang menyerahkan Surat Pemberitahuan (SPT) hanya 8,5 juta Wajib Pajak. Padahal, penduduk yang aktif bekerja ada 110 juta orang. Artinya rasio Surat Pemberitahuan (SPT) terhadap kelompok pekerja aktif itu hanya 7,7 persen. Dengan kata lain memang tingkat kepatuhan Wajib Pajak masih belum memadai. (kompas.com, 30 September 2011).

Data yang dimiliki Ditjen Pajak hingga tahun lalu, yang punya Nomor Pokok Wajib Pajak (NPWP) hanya 24,812 juta. Wajib Pajak itu terdiri dari 22,131 juta Wajib Pajak Orang Pribadi, 2,136 Wajib Pajak Badan dan 545.232 Wajib Pajak Bendaharawan, jadi masih ada 40 juta yang belum bayar pajak. Data Badan Pusat Statistik (BPS) pun terlihat bahwa jumlah usia kerja di Indonesia mencapai 110 juta pekerja, dimana 60 juta masuk golongan di atas Penghasilan Tidak Kena Pajak (PTKP) dan sisanya berpenghasilan di bawah Penghasilan Tidak Kena pajak (PTKP). Seperti diketahui, kenaikan Penghasilan Tidak Kena Pajak (PTKP) tahun ini hampir 53,4\% dari Rp 15,84 juta menjadi Rp 24,3 juta untuk penghasilan per tahunnya. (nasional.kontan.co.id, 7 Mei 2013).

Berdasarkan Pasal 7 Undang-Undang Ketentuan Umum dan Tata Cara Perpajakan Nomor 28 Tahun 2007 menyatakan bahwa Wajib Pajak yang diharuskan menyerahkan Surat Pemberitahuan (SPT) sebaiknya menghindari kemungkínan terkena denda pajak senilai Rp 100.000 per orang. Denda ini bisa dikenakan jika Wajib Pajak Orang Pribadi terlambat menyampaikan Surat Pemberitahuan (SPT) tahunan.

Tabel 1. Wajib Pajak Orang Pribadi Terdaftar, Wajib Pajak Orang Pribadi yang Menyampaikan SPT Tahunan, dan Tingkat Kepatuhan Wajib Pajak Orang Pribadi

\begin{tabular}{|c|c|c|c|}
\hline Tahun & $\begin{array}{c}\text { Wajib Pajak Orang } \\
\text { Pribadi Terdaftar }\end{array}$ & $\begin{array}{c}\text { Wajib Pajak Orang Pribadi yang } \\
\text { Menyampaikan SPT Tahunan }\end{array}$ & $\begin{array}{c}\text { Tingkat Kepatuhan Wajib } \\
\text { Pajak Orang Pribadi }\end{array}$ \\
\hline $\mathbf{2 0 1 0}$ & 63.681 & 32.070 & $48,20 \%$ \\
\hline $\mathbf{2 0 1 1}$ & 83.670 & 37.649 & $43,85 \%$ \\
\hline $\mathbf{2 0 1 2}$ & 70.177 & 39.305 & $55,22 \%$ \\
\hline
\end{tabular}

Dari tabel diatas dapat dilihat peningkatan jumlah Wajib Pajak Orang Pribadi yang terdaftar mengalami peningkatan pada tahun 2011 dan mengalami penurunan kembali pada tahun 2012. Akan tetapi terdapat perbedaan yang sangat signifikan antara jumlah Wajib Pajak yang terdaftar dengan jumlah Surat Pemberitahuan (SPT) yang dilaporkan. Selain itu dari segi kepatuhan Wajib Pajak Orang Pribadi juga menunjukan penurunan pada tahun 2011 dan kenaikan pada tahun 2012. 
Berdasarkan uraian di atas, penulis tertarik untuk melakukan penelitian mengenai masalah tersebut dengan judul: "PENGARUH PENGETAHUAN PERATURAN PERPAJAKAN DAN KUALITAS PELAYANAN TERHADAP KEPATUHAN WAJIB PAJAK PADA KANTOR PELAYANAN PAJAK PRATAMA BANDUNG KAREES (Kasus Pada Wajib Pajak Orang Pribadi Pada KPP Pratama Bandung Karees)."

\subsection{Tujuan Penelitian}

Untuk mengetahui persepsi Wajib Pajak Orang Pribadi atas pengetahuan peraturan perpajakan dan kualitas pelayanan pada Kantor Pelayanan Pajak Pratama Bandung Karees, Untuk mengetahui bagaimana persepsi Petugas Pajak atas kepatuhan Wajib Pajak Orang Pribadi yang terjadi di Kantor Pelayanan Pajak Pratama Bandung Karees, Untuk mengetahui pengaruh persepsi Wajib Pajak atas pengetahuan peraturan perpajakan terhadap kepatuhan Wajib Pajak Orang Pribadi pada Kantor Pelayanan Pajak Pratama Bandung Karees, Untuk mengetahui pengaruh persepsi Wajib Pajak atas kualitas pelayanan terhadap kepatuhan Wajib Pajak Orang Pribadi pada Kantor Pelayanan Pajak Pratama Bandung Karees, Untuk mengetahui pengaruh antara persepsi Wajib Pajak atas pengetahuan peraturan perpajakan dan kualitas pelayanan terhadap kepatuhan Wajib Pajak Orang Pribadi pada Kantor Pelayanan Pajak Pratama Bandung Karees.

\subsection{Tinjauan Pustaka Dan Lingkup Penelitian 1.3.1 Definisi Pajak}

Menurut Ketentuan Umum dan Tata Cara Perpajakan Pasal 1 Undang-Undang Nómor 28 Tahun 2007, "Pajak adalah kontribusi Wajib Pajak kepada Negara yang terutang oleh orang pribadi atau badan yang bersifat memaksa berdasarkan undang-undang, dengan tidak mendapatkan imbalan secara langsung dan digunakan untuk keperluan negara bagi sebesar-besarnya kemakmuran rakyat.

Definisi pajak menurut Rahayu (2010:21)

\subsubsection{Pengetahuan Peraturan Perpajakan}

Mengetahui dan memahami peraturan perpajakan bagi setiap Wajib Pajak merupakan suatu keharusan. Karena dengan mengetahui dan memahami peraturan perpajakan, seorang Wajib Pajak akan lebih mudah untuk menjalankan kewajiban dalam membayar pajaknya, selain itu jika Wajib Pajak mengetahui dan memahami tentang peraturan perpajakan maka akan terhindar dari sanksi pajak.

Cara mengetahui peraturan perpajakan bagi Wajib Pajak tidaklah sulit, karena pada saat ini media informasi (seperti internet) telah memudahkan setiap Wajib Pajak untuk dapat mengetahui peraturan perpajakan yang terbaru. Selain melalui media informasi, pengetahuan tentang perpajakan dapat diperoleh melalui sosialisasi dari petugas pajak ataupun dengan mengikuti pelatihan pajak.

Setelah Wajib Pajak mengetahui tentang peraturan perpajakan, diharapkan kepada semua Wajib Pajak untuk dapat memahami peraturan perpajakan, sehingga Wajib Pajak dapat lebih mengerti hak dan kewajiban sebagai Wajib Pajak, serta akan memudahkan Wajib Pajak dalam menjalankan kewajiban perpajakannya.

\subsubsection{Kualitas Pelayanan}

Menurut Zain (2007:35), para petugas dari instansi pajak hendaknya dilatih untuk memahami bahwa para Wajib Pajak bukanlah merupakan lawan akan tetapi lebih merupakan anggota masyarakat yang perlu ditolong dalam rangka memenuhi kewajiban perpajakannya atau dengan perkataan lain, rasa hormat-menghormati dan respek hendaknya muncul dari kedua belah pihak.

\subsubsection{Kepatuhan Wajib Pajak}

Menurut Rahayu (2010:139) mengatakan bahwa "kepatuhan WajibPajak adalah tindakan Wajib Pajak yang taat dan memenuhi serta melaksanakan kewajiban perpajakan sesuai dengan ketentuan peraturan perundang-undangan perpajakan.

Menurut Rahayu (2010:149) menyatakan bahwa ada beberapa penyebab Wajib Pajak tidak patuh yaitu: 1. Fitrah penghasilan yang diperoleh Wajib Pajak yang utama ditujukan untuk pemenuhan hidupnya. Pada saat telah memenuhi ketentuan perpajakan timbul kewajiban pembayaran pajak kepada negara. 
Timbul konflik, antara kepentingan sendiri dan kepentingan negara. Pada umumnya kepentingan pribadi yang selalu dimenangkan.

2. Wajib Pajak kurang sadar tentang kewajiban bernegara, tidak patuh pada peraturan, dan kurang menghargai hukum.

Menurut Rahayu (2010:138), menjelaskan "Ada dua macam kepatuhan yaitu: (1). Kepatuhan formal adalah suatu keadaan dimana wajib pajak memenuhi kewajiban secara formal sesuai dengan ketentuan dalam Undang-Undang Perpajakan. (2). Kepatuhan material adalah suatu keadaan dimana wajib pajak secara substantif atau hakikatnya memenuhi semua ketentuan material perpajakan, yakni sesuai isi dan jiwa Undang-Undang Perpajakan.”

\section{METODE PENELITIAN}

\subsection{Jenis Penelitian}

Dalam melakukan penelitian ini penulis menggunakan metode deskriptif verifikatif yang bersifat kausalitas. Penelitian deskriptif adalah penelitian yang dilakukan untuk mengetahui dan menjadi mampu untuk menjelaskan karakteristik variabel yang diteliti dalam suatu situasi.

Penelitian verifikatif yang bersifat kausalitas disusun untuk meneliti kemungkinan adanya hubungan sebab akibat antar variabel (Sanusi, 2011: 14).

\subsection{Operasional Variabel}

Sekaran (2009:115), variabel adalah apapun yang dapat membedakan atau membawa variasi pada nilai. Nilai bisa berbeda pada berbagai waktu untuk objek atau orang yang sama, atau páda waktu yang sama untuk objek atau orang yang berbeda.

Dalam penelitian ini, menurut hubungan antara satu variabel dengan variabel yang lain, maka variabel yang digunakan adalah variabel independen (variabel bebas) dan variabel dependen (variabel terikat).

\subsubsection{Variabel Independen (Variabel Bebas)}

Variabel independen menurut Sekaran (2009: 117), adalah variabel yang mempengaruhi variabel terikat, entah secara positif atau negatif. Jika terdapat variabel bebas, yariabel terikat juga hadir, dan dengan setiap unit kenaikan dalam variabel bebas, terdapat pula kenaikan atau penurunan dalam variabel terikat.

Dalam penelitian ini terdapat dua variabel independen yang digunakan yaitu:

\section{Pengetahuan Peraturan Perpajakan $\left(X_{1}\right)$}

Mengetahui dan memahami peraturan perpajakan bagi setiap wajib pajak merupakan suatu keharusan, karena dengan mengetahui dan memahami peraturan perpajakan, seorang wajib pajak akan lebih mudah untuk menjalankan kewajiban dalam membayar pajaknya, selain itu jika wajib pajak mengetahui dan memahami tentang peraturan perpajakan, maka akan terhindar dari sanksi pajak.

\section{Kualitas Pelayanan $\left(\mathbf{X}_{2}\right)$}

Dalam usaha mengembangkan iklim perpajakan yang sehat, ialah mengembangkan dan meningkatkan pelayanan terhadap wajib pajak. Para petugas pada instansi pajak, hendaknya dilatih untuk memahami bahwa para wajib pajak bukanlah merupakan lawan akan tetapi lebih merupakan anggota masyarakat yang perlu ditolong dalam rangka memenuhi kewajiban perpajakannya atau dengan perkataan lain, rasa hormat menghormati hendaknya muncul dari kedua belah pihak.

\subsubsection{Variabel Dependen (Variabel Terikat)}

Menurut Sekaran (2009: 116), "variabel dependen merupakan variabel yang menjadi perhatian utama peneliti. Dengan kata lain, variabel terikat merupakan variabel utama yang menjadi faktor yang berlaku dalam investigasi."

Dalam penelitian ini terdapat satu variabel dependen yang digunakan yaitu:

\section{Kepatuhan Wajib Pajak (Y)}

Kepatuhan Wajib Pajak adalah tindakan wajib pajak dalam pemenuhan kewajiban perpajakannya sesuai dengan ketentuan perundang-undangan dan peraturan pelaksanaan perpajakan yang berlaku dalam suatu negara.

Tabel 2. Operasional Variabel

\begin{tabular}{|c|c|c|c|}
\hline Variabel & Konsep Variabel & Indikator & Skala \\
\hline
\end{tabular}




\begin{tabular}{|c|c|c|c|}
\hline \multirow{6}{*}{$\begin{array}{l}\text { Pengetahuan } \\
\text { Peraturan } \\
\text { Perpajakan } \\
\quad\left(\mathrm{X}_{1}\right)\end{array}$} & \multirow{6}{*}{$\begin{array}{l}\text { Mengetahui dan memahami } \\
\text { peraturan perpajakan bagi setiap } \\
\text { wajib pajak merupakan suatu } \\
\text { keharusan. Karena dengan } \\
\text { mengetahui dan memahami } \\
\text { peraturan perpajakan, seorang wajib } \\
\text { pajak akan lebih mudah untuk } \\
\text { menjalankan kewajiban dalam } \\
\text { membayar pajaknya, selain itu jika } \\
\text { wajib } \\
\text { pajakmengetahuidanmemahamitent } \\
\text { ang peraturanperpajakan, maka akan } \\
\text { terhindar dari sanksi pajak. } \\
\text { (Utami, Andi, dan Ayu, 2012) }\end{array}$} & $\begin{array}{ll}\text { a. } & \text { Kepemilikan Nomor Pokok } \\
\text { Wajib Pajak (NPWP). }\end{array}$ & \multirow[t]{6}{*}{ Ordinal } \\
\hline & & $\begin{array}{l}\text { b. Pengetahuan dan pemahaman } \\
\text { mengenai hak dan kewajiban. }\end{array}$ & \\
\hline & & $\begin{array}{l}\text { c. Pengetahuan dan pemahaman } \\
\text { mengenai sanksi perpajakan. }\end{array}$ & \\
\hline & & $\begin{array}{l}\text { d. Pengetahuan dan pemahaman } \\
\text { mengenaiPenghasilan Tidak } \\
\text { Kena Pajak (PTKP), Penghasilan } \\
\text { Kena Pajak (PKP), dan Tarif } \\
\text { Pajak. } \\
\end{array}$ & \\
\hline & & $\begin{array}{l}\text { e. Mengetahui dan memahami } \\
\text { peraturan perpajakan melalui } \\
\text { sosialisasi yang dilakukan oleh } \\
\text { KPP. }\end{array}$ & \\
\hline & & $\begin{array}{l}\text { f. Mengetahui dan memahami } \\
\text { peraturan pajak melalui training } \\
\text { perpajakan yang mereka ikuti. } \\
\text { (Utami, Andi, dan Ayu, 2012) }\end{array}$ & \\
\hline \multirow{5}{*}{$\begin{array}{l}\text { Kualitas } \\
\text { Pelayanan } \\
\quad\left(\mathrm{X}_{2}\right)\end{array}$} & \multirow{5}{*}{$\begin{array}{l}\text { Pelayanan adalah sentra dan } \\
\text { indikator utama untuk membangun } \\
\text { citra Direktorat Jendral Pajak, } \\
\text { sehingga kualitas pelayanan harus } \\
\text { terus menerus ditingkatkan dalam } \\
\text { rangka mewujudharapan dan } \\
\text { membangun kepercayaanWajib } \\
\text { Pajak dan seluruh stakeholder } \\
\text { perpajakan terhadap Direktorat } \\
\text { Jendral Pajak. } \\
\text { (Surat Edaran Direktur Jenderal } \\
\text { Pajak No. SE-45/PJ/2007) }\end{array}$} & a. Reliability (keandalan). & \multirow[t]{5}{*}{ Ordinal } \\
\hline & & b. Responsiveness (tanggapan). & \\
\hline & & c. Assurance (kepastian). & \\
\hline & & d. Empathy (empati). & \\
\hline & & $\begin{array}{l}\text { e. Tangible (nyata). } \\
\text { (Zeithaml, 2006: 116) }\end{array}$ & \\
\hline \multirow{4}{*}{$\begin{array}{l}\text { Kepatuhan } \\
\text { Wajib Pajak } \\
\text { (Y) }\end{array}$} & \multirow{4}{*}{$\begin{array}{l}\text { Kepatuhan WajibPajak } \\
\text { adalahtindakan WajibPajak yang } \\
\text { taatdanmemenuhisertamelaksanaka } \\
\text { nkewajibanperpajakansesuaidengan } \\
\text { ketentuanperaturanperundang- } \\
\text { undanganperpajakan. } \\
\text { (Rahayu, 2010) }\end{array}$} & $\begin{array}{l}\text { Mengisi formulir pajak dengan } \\
\text { lengkap dan jelas. }\end{array}$ & \multirow[t]{4}{*}{ Ordinal } \\
\hline & & $\begin{array}{l}\text { b. Menghitung jumlah pajak yang } \\
\text { terutang dengan benar. }\end{array}$ & \\
\hline & & $\begin{array}{l}\text { c. Membayar pajak yang terutang } \\
\text { tepat pada waktunya. }\end{array}$ & \\
\hline & & $\begin{array}{l}\text { d. Menyampaikan/ melaporkan Surat } \\
\text { Pemberitahuan (SPT) tepat pada } \\
\text { waktunya. } \\
\text { (Rahayu, 2010) }\end{array}$ & \\
\hline
\end{tabular}

\subsubsection{Populasi dan Sampel}

Populasi menurut Sugiyono (2011:80) adalah wilayah generalisasi yang terdiri atas: obyek/subyek yang mempunyai kualitas dan karakteristik tertentu yang ditetapkan oleh peneliti untuk dipelajari dan kemudian ditarik kesimpulannya. Dalam penelitian ini, populasinya adalah 70.177 dari Wajib Pajak Orang Pribadi yang terdaftar tahun 2012 di KPP Bandung Karees, 22 orang dari Account Representative, dan 11 orang dari Pemeriksa Pajak yang bertugas di KPP Bandung Karees.

Sampel adalah sebagian dari jumlah dan karakteristik yang dimiliki oleh populasi tersebut (Sugiyono, 2011:81). Jumlah sampel dalam penelitian ini adalah sebanyak 133 responden dengan rincian 100 responden dari wajib pajak orang pribadi, 22 responden dari Account Representative (AR) dan 11 responden dari Pemeriksa Pajak.

\subsubsection{Teknik Analisis Data}

Metode kualitatif yaitu metode pengolahan data yang dinyatakan dengan kalimat secara deskriptif. 


\section{HASIL PENELITIAN DAN PEMBAHASAN}

\subsection{Karakteristik Responden}

Responden yang ditetapkan oleh penulis bertujuan untuk menganalisis dan mengukur ada atau tidaknya pengaruh dari pengetahuan peraturan perpajakan dan kualitas pelayanan terhadap kepatuhan wajib pajak. Tabel 3.1 menunjukkan karakteristik responden berdasarkan umur, jenis kelamin, jenis pekerjaan, pendidikan terakhir.

Tabel 3. Karakteristik Responden

\begin{tabular}{|c|c|c|c|c|c|c|c|}
\hline No. & $\begin{array}{c}\text { Karakteristik } \\
\text { Responden }\end{array}$ & $\mathbf{F}$ & $\%$ & No. & Karakteristik Responden & $\mathbf{f}$ & $\%$ \\
\hline 1. & \multicolumn{3}{|c|}{ Berdasarkan Umur WPOP } & 7. & \multicolumn{3}{|c|}{ Berdasarkan Jenis Pekerjaan WPOP } \\
\hline & $\leq 25$ Tahun & 23 & $23 \%$ & & PNS & 12 & $12 \%$ \\
\hline & $26-35$ Tahun & 36 & $36 \%$ & & Karyawan & 55 & $55 \%$ \\
\hline & $36-45$ Tahun & 23 & $23 \%$ & & Konsultan & 3 & $3 \%$ \\
\hline & $>45$ Tahun & 18 & $18 \%$ & & Wiraswasta & 23 & $23 \%$ \\
\hline & Total & 100 & $100 \%$ & & Pensiunan & 7 & $7 \%$ \\
\hline 2. & \multicolumn{3}{|c|}{ Berdasarkan Umur AR } & & Total & 100 & $100 \%$ \\
\hline & $\leq 25$ Tahun & 0 & $0 \%$ & 8. & \multicolumn{3}{|c|}{ Berdasrkan Jenis Pekerjaan Fiskus } \\
\hline & $26-35$ Tahun & 12 & $54,54 \%$ & & $\mathrm{AR}$ & 22 & $66,67 \%$ \\
\hline & 36 - 45 Tahun & 9 & $40,91 \%$ & & Pemeriksa Pajak & 11 & $33,33 \%$ \\
\hline & $>45$ Tahun & 1 & $4,55 \%$ & & Total & 33 & $100 \%$ \\
\hline & Total & 22 & $100 \%$ & 9. & \multicolumn{3}{|c|}{ Berdasarkan Pendidikan Terakhir WPOP } \\
\hline 3. & \multicolumn{3}{|c|}{ Berdasarkan Umur Pemeriksa Pajak } & & SMA & 36 & $36 \%$ \\
\hline & $\leq 25$ Tahun & 1 & $9,10 \%$ & & D3 & 21 & $21 \%$ \\
\hline & $26-35$ Tahun & 7 & $63,62 \%$ & & $\mathrm{~S} 1$ & 37 & $37 \%$ \\
\hline & 36 - 45 Tahun & 2 & $18,18 \%$ & & $\mathrm{~S} 2$ & 3 & $3 \%$ \\
\hline & $>45$ Tahun & 1 & $9,10 \%$ & & Lain-lain & 3 & $3 \%$ \\
\hline & Total & 11 & $100 \%$ & & Total & 100 & $100 \%$ \\
\hline 4. & \multicolumn{3}{|c|}{ Berdasarkan Jenis Kelamin WPOP } & 10. & \multicolumn{3}{|c|}{ Berdasrkan Pendidikan Terakhir AR } \\
\hline & Laki-laki & 63 & $63 \%$ & & D3 & 3 & $13,60 \%$ \\
\hline & Perempuan & 37 & $37 \%$ & 7 & $\mathrm{~S} 1$ & 16 & $72,80 \%$ \\
\hline & Total & 100 & $100 \%$ & & $\mathrm{~S} 2$ & 3 & $13,60 \%$ \\
\hline 5. & \multicolumn{3}{|c|}{ Berdasarkan Jenis Kelamin AR } & & Total & 22 & $100 \%$ \\
\hline & Laki-laki & & $64 \%$ & 11. & \multicolumn{3}{|c|}{$\begin{array}{l}\text { Berdasarkan Pendidikan Terakhir Pemeriksa } \\
\text { Pajak }\end{array}$} \\
\hline & Perempuan & 8 & $37 \%$ & & D3 & 4 & $36,40 \%$ \\
\hline & Total & 22 & $100 \%$ & & S1 & 5 & $45,40 \%$ \\
\hline 6. & \multicolumn{3}{|c|}{ Berdasarkan Jenis Kelamin Pemeriksa Pajak } & & $\mathrm{S} 2$ & 2 & $18,20 \%$ \\
\hline & Laki-laki & 8 & $73 \%$ & & Total & 11 & $100 \%$ \\
\hline & Perempuan & 3 & $27 \%$ & & & & \\
\hline & Total & 11 & $100 \%$ & & & & \\
\hline
\end{tabular}

\subsection{Uji Validitas dan Uji Reliabilitas}

\subsubsection{Uji Validitas}

Dengan demikian data yang valid adalah data "yang tidak berbeda" antar data yang dilaporkan oleh peneliti dengan data yang sesungguhnya yang terjadi pada objek penelitian.

Tabel 4. Hasil Uji Validitas

\begin{tabular}{|c|c|c|c|c|}
\hline Variabel & No. Item & r hitung & r tabel & Kesimpulan \\
\hline Pengetahuan & 1 & 0,355 & 0,197 & Valid \\
\cline { 2 - 5 } Peraturan & 2 & 0,287 & 0,197 & Valid \\
\cline { 2 - 5 } $\begin{array}{c}\text { Perpajakan } \\
\left(\mathrm{X}_{1}\right)\end{array}$ & 3 & 0,485 & 0,197 & Valid \\
\cline { 2 - 5 } & 4 & 0,568 & 0,197 & Valid \\
\hline
\end{tabular}




\begin{tabular}{|c|c|c|c|c|}
\hline Variabel & No. Item & r hitung & $r$ tabel & Kesimpulan \\
\hline & 5 & 0,512 & 0,197 & Valid \\
\hline & 6 & 0,492 & 0,197 & Valid \\
\hline \multirow{10}{*}{$\begin{array}{l}\text { Kualitas } \\
\text { Pelayanan } \\
\left(\mathrm{X}_{2}\right)\end{array}$} & 1 & 0,460 & 0,197 & Valid \\
\hline & 2 & 0,500 & 0,197 & Valid \\
\hline & 3 & 0,695 & 0,197 & Valid \\
\hline & 4 & 0,711 & 0,197 & Valid \\
\hline & 5 & 0,386 & 0,197 & Valid \\
\hline & 6 & 0,702 & 0,197 & Valid \\
\hline & 7 & 0,527 & 0,197 & Valid \\
\hline & 8 & 0,593 & 0,197 & Valid \\
\hline & 9 & 0,476 & 0,197 & Valid \\
\hline & 10 & 0,562 & 0,197 & Valid \\
\hline \multirow{4}{*}{$\begin{array}{c}\text { Kepatuhan } \\
\text { Wajib Pajak } \\
\text { (Y) }\end{array}$} & 1 & 0,649 & 0,344 & Valid \\
\hline & 2 & 0,741 & 0,344 & Valid \\
\hline & 3 & 0,677 & 0,344 & Valid \\
\hline & 4 & 0,481 & 0,344 & Valid \\
\hline
\end{tabular}

Keterangan :

*) = Dapat dikatakan valid apabila $\mathrm{r}$ hitung lebih besar dari $\mathrm{r}$ tabel

\subsubsection{Uji Reliabilitas}

Pengukuran keandalan butir pertanyaan dengan sekali menyebarkan kuesioner pada responden, kemudian hasil skornya diukur korelasinya antar skor jawaban pada butir pertanyaan yang sama dengan bantuan software SPSS 17.0, dengan fasilitas Cronbach's Alpha ( $\alpha$ ). Suatu konstruk atau variabel dikatakan reliabel jika memberikan nilai Cronbach's Alpha >0,60

Tabel 5. Hasil Uji Reliabilitas

\begin{tabular}{|c|l|c|c|}
\hline No. & \multicolumn{1}{|c|}{ Variabel } & Cronbach's Alpha & Kesimpulan \\
\hline $\mathbf{1}$ & Pengetahuan Peraturan Perpajakan (variabel $\mathrm{X}_{1}$ ) & 0,713 & Reliabel \\
\hline $\mathbf{2}$ & Kualitas Pelayanan (variabel $\mathrm{X}_{2}$ ) & 0,856 & Reliabel \\
\hline $\mathbf{3}$ & Kepatuhan Wajib Pajak (variabel Y) & 0,815 & Reliabel \\
\hline
\end{tabular}

Keterangan :

*) = Dapat dikatakan reliabel apabila nilái Cronbach Alpha> 0,60

\subsection{Analisis Deskriptif}

Pada bagian ini akan dijelaskan hasil penelitian yang diperoleh dengan memberikan penilaian atas jawaban responden dalam menetapkan peringkat dalam Pengetahuan Peraturan Perpajakan, Kualitas Pelayanan, dan Kepatuhan Wajib Pajak dapat dilihat dari perbandingan antara skor aktual dengan skor ideal sebagai berikut:

Keterangan:

$$
\% \text { Skor Aktual }=\frac{\text { Skor Aktual }}{\text { Skor Ideal }} \times 100 \%
$$

a. Skoraktual adalah jawaban seluruh responden atas kuesioner yang telah diajukan

b. Skor ideal adalah skor atau bobot tertinggi atau semua responden diasumsikan memilih jawaban dengan skor tertinggi.

Dengan kriteria berdasarkan tabel berikut:

Tabel 5. Kriteria Skor Jawaban Responden Berdasarkan Persentase Skor Aktual

\begin{tabular}{|c|c|c|}
\hline No. & Persentase Skor & Kategori Skor \\
\hline 1. & $20,00-36,00$ & Sangat Tidak Baik \\
\hline 2. & $36,01-52,00$ & Kurang Baik \\
\hline 3. & $52,01-68,00$ & Cukup Baik \\
\hline
\end{tabular}




\begin{tabular}{|c|c|c|}
\hline No. & Persentase Skor & Kategori Skor \\
\hline 4. & $68,01-84,00$ & Baik \\
\hline 5. & $84,01-100$ & Sangat Baik \\
\hline
\end{tabular}

\section{a. Pembahasan Analisis Deskriptif Pengetahuan Peraturan Perpajakan}

Berdasarkan hasil rekapitulasi persentase total skor tanggapan responden mengenai Pengetahuan Peraturan Perpajakan diatas, dapat dilihat bahwa Pengetahuan Peraturan Perpajakan pada KPP Pratama Bandung Karees berada pada kategori Baik yaitu sebesar 83,93\%. Artinya, Wajib Pajak Orang Pribadi menilai bahwa Pengetahuan Peraturan Perpajakan baik untuk pemenuhan kepatuhan Wajib Pajak.

\section{b. Pembahasan Analisis Deskriptif Kualitas Pelayanan}

Berdasarkan hasil rekapitulasi persentase total skor tanggapan responden mengenai kualitas pelayanan diatas, dapat dilihat bahwa kualitas pelayanan pada KPP Pratama Bandung Karees berada pada kategori baik yaitu sebesar $78,04 \%$. Artinya, kualitas pelayanan telah baik dalam menjalankan tugasnya untuk pemenuhan kepatuhan Wajib Pajak. Sehingga dengan kualitas pelayanan yang baik diharapkan Wajib Pajak Orang pribadi tidak akan melakukan pelanggaran dan memenuhi kewajiban perpajakan sesuai dengan ketentuan yang berlaku.

\section{c. Pembahasan Analisis Deskriptif Kepatuhan Wajib Pajak}

Berdasarkan hasil rekapitulasi persentase total skor tanggapan responden mengenai kepatuhan Wajib Pajak diatas, dapat dilihat bahwa tingkat kepatuhan Wajib Pajak Orang Pribadí pada KPP Pratama Bandung Karees berada pada kategori Cukup Baik sebesar 58,78\%. Artinya, Wajib Pajak Orang Pribadi telah mematuhi kewajiban perpajakannya.

\subsection{Uji Asumsi Klasik}

\subsubsection{Uji Normalitas}

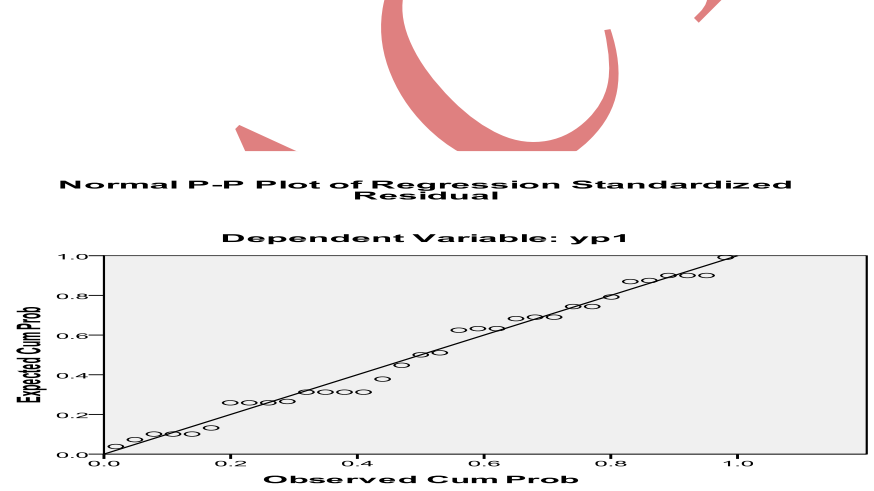

Gambar 2. Uji Normalitas

Berdasarkan gambar 2 diatas, dápat diketahui bahwa jika pada grafik normal plot terlihat titik-titik menyebar disekitar garis diagonal dan mengikuti arah garis diagonal atau grafik histogramnya menunjukan pola distribusi normal, maka model regresi memenuhi asumsi normalitas.

\subsubsection{Uji Heteroskedasitas}

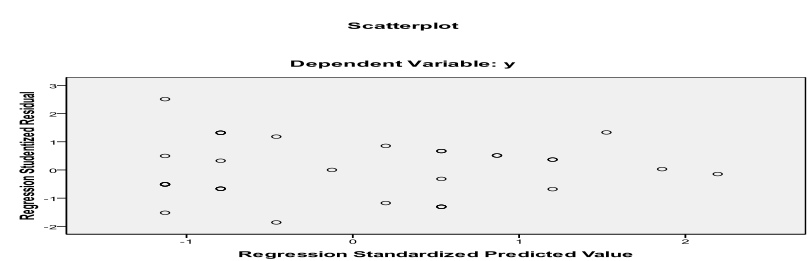

Gambar 3. Uji Heteroskedasitas

Grafik scatterplot pada gambar 3 memperlihatkan bahwa titik-titik menyebar secara acak serta tersebar baik di atas maupun di bawah angka 0 pada sumbu Y.

\subsubsection{Uji Multikolinearitas}


Tabel 6. Uji Multikolinearitas

\begin{tabular}{|ll|c|c|}
\hline \multicolumn{1}{|c|}{ Model } & Tolerance & VIF \\
\hline \multirow{3}{*}{1} & (Constant) & & \\
& X1 & .958 & 1.044 \\
& X2 & .958 & 1.044 \\
\hline
\end{tabular}

Berdasarkan tabel 6 diatas, hasil nilai tolerance menujukkan tidak ada variabel independen yaitu Pengetahuan Peraturan Perpajakan $\left(\mathrm{X}_{1}\right)$ dan Kualitas Pelayanan $\left(\mathrm{X}_{2}\right)$ yang memiliki nilai tolerance kurang dari 0,10 yang berarti tidak ada kolerasi antara variabel independen. Hasil nilai VIF juga menunjukkan hal yang sama, tidak ada variabel independen Pengetahuan Peraturan Perpajakan $\left(\mathrm{X}_{1}\right)$ dan Kualitas Pelayanan $\left(\mathrm{X}_{2}\right)$ yang memiliki nilai VIF lebih dari 10.

\subsection{Analisis Koefisien determinasi $\left(\mathbf{R}^{2}\right)$}

Tabel 7. KoefisienDeterminasi Model Summary

\begin{tabular}{|c|c|c|c|c|}
\hline Model & R & R Square & Adjusted R Square & Std. Error of the Estimate \\
\hline 1 & $.439^{\mathrm{a}}$ & .193 & .139 & 1.03585 \\
\hline
\end{tabular}

a. Predictors: (Constant), x2p1, x1p1

b. Dependent Variable: yp1

Pada tabel 7 menunjukan bahwa koefisien determinasi diperoleh nilai $R$ Square sebesar 0,193. Hal ini berarti bahwa 19,3\% variabel dependen yaitu Kepatuhan Wajib Pajak dapat dipengaruhi oleh variabel independen yaitu Pengetahuan Peraturan Perpajakan dan Kualitas Pelayanan, sedangkan sisanya sebesar 80,7\% dapat dipengaruhi oleh variabel atau faktor-faktor lain di luar variabel penelitian.

\subsection{Analisis Regresi}

Analisis ini untuk menguji variabel independen, dimana dalam penelitian ini adalah Pengetahuan Peraturan Perpajakan dan Kualitas Pelayanan dalam mempengaruhi variabel dependen yaitu Kepatuhan Wajib Pajak. Secara sistematik persamaan tersebut dirumuskan sebagai berikut:

Keterangan:

$$
Y=\alpha+\beta_{1} X_{1}+\beta_{2} X_{2}
$$

$\mathrm{Y} \quad=$ Kepatuhan Wajib Paják

$\alpha=$ Konstanta (tetap)

$\beta_{1}, \beta_{2}=$ Koefisien Regresi

$\mathrm{X}_{1}=$ Pengetahuan Peraturan Perpajakan

$\mathrm{X}_{2}=$ Kualitas Pelayanan

Dengan menggunakan software SPSS, diperoleh hasil analisis regresi linier berganda sesuai dengan tabel 4.25 berikut:

Tabel 8. Koefisien Regresi Berganda 


\begin{tabular}{|c|c|c|c|c|c|c|}
\hline \multicolumn{7}{|c|}{ Coefficients $^{\mathrm{a}}$} \\
\hline & \multirow{2}{*}{ Model } & \multicolumn{2}{|c|}{$\begin{array}{c}\text { Unstandardized } \\
\text { Coefficients }\end{array}$} & \multirow{2}{*}{\begin{tabular}{|c|}
$\begin{array}{c}\text { Standardized } \\
\text { Coefficients }\end{array}$ \\
Beta \\
\end{tabular}} & \multirow[t]{2}{*}{$\mathbf{T}$} & \multirow{2}{*}{ Sig. } \\
\hline & & B & Std. Error & & & \\
\hline \multirow[t]{3}{*}{1} & (Constant) & 6.580 & 1.329 & & 4.951 & .000 \\
\hline & $\mathrm{x} 1 \mathrm{p} 1$ & -.651 & .282 & -.386 & -2.305 & .028 \\
\hline & $\mathrm{x} 2 \mathrm{p} 1$ & -.164 & .191 & -.144 & -.859 & .397 \\
\hline
\end{tabular}

a. Dependent Variable: yp1

Berdasarkan hasil output pada tabel 8 diperoleh nilai $\alpha$ (konstanta) sebesar 6,580 , nilai $\beta_{1}$ sebesar $-0,651$ dan $\beta_{2}$ sebesar $-0,164$. Dengan demikian dapat dibentuk persamaan regresi linier berganda sebagai berikut:

$$
\mathrm{Y}=6,580-0,651 \mathrm{X}_{1}-0,164 \mathrm{X}_{2}
$$

Berdasarkan persamaan di atas dapat diinterpretasikan sebagai berikut:

1. Konstanta sebesar 6,580 menyatakan bahwa jika variabel Pengetahuan Peraturan Perpajakan $\left(X_{1}\right)$ dan Kualitas Pelayanan $\left(\mathrm{X}_{2}\right)$ bernilai 0 maka Kepatuhan Wajib Pajak pada KPP Pratama Bandung Karees akan bernilai positif dengan nilai 6,580.

2. Koefisien regresi Pengetahuan Peraturan Perpajakan ( $\left.X_{1}\right)$ bernilai negatif sebesar -0,651 menyatakan bahwa jika Pengetahuan Peraturan Perpajakan meningkat sebesar 1 satuan dan variabel lainnya konstan, maka Kepatuhan Wajib Pajak Orang Pribadi pada KPP Pratama Bandung Karees akan menurun sebesar $-0,651$ satuan.

3. Koefisien regresi Kualitas Pelayanan $\left(\mathrm{X}_{2}\right)$ bernilai negatif sebesar $-0,164$ menyatakan bahwa jika Kualitas Pelayanan meningkat sebesar 1 satuan dan variabel lainnya konstan, maka Kepatuhan Wajib Pajak Orang Pribadi pada KPP Pratama Bandung Karees akan menurun sebesar -0,164 satuan.

\subsection{Uji Hipotesis}

\subsubsection{Uji T (pengaruh secara Parsial)}

Berdasarkan tabel 3.7 di atas, dapat diketahui nilai signifikansi pada variabel Pengetahuan Peraturan Perpajakan $\left(X_{1}\right)$ lebih kecil dari 0,05 yaitu sebesar 0,028. Sehingga dapat disimpulkan bahwa $\mathrm{Ho}_{1}$ ditolak dan $\mathrm{Ha}_{1}$ diterima. Artinya Pengetahuan Peraturan Perpajakan mempunyai pengaruh signifikan terhadap Kepatuhan Wajib Pajak

Selain itu, berdasarkan tabel 3.7 di atas, dapat diketahui nilai signifikansi pada variabel Kualitas Pelayanan $\left(\mathrm{X}_{2}\right)$ lebih besar dari 0,05 yaitu sebesar 0,397. Sehingga dapat disimpulkan bahwa $\mathrm{Ho}_{2}$ diterima dan $\mathrm{Ha}_{2}$ ditolak. Artinya Kualitas Pelayanan tidak mempunyai pengaruh signifikan terhadap Kepatuhan Wajib Pajak.

\subsubsection{Uji F (Pengujian secara simultan)}

Tabel 9. Uji Signifikansi Simultan (Uji F)

ANOVA $^{\text {b }}$

\begin{tabular}{|rl|r|r|r|r|r|}
\hline \multicolumn{1}{|l|}{ Model } & Sum of Squares & Df & Mean Square & F & Sig. \\
\hline 1 & Regression & 7.689 & 2 & 3.845 & 3.583 & $.040^{\mathrm{a}}$ \\
& Residual & 32.189 & 30 & 1.073 & & \\
& Total & 39.879 & 32 & & & \\
\hline
\end{tabular}

a. Predictors: (Constant), x2p1, x1p1

b. Dependent Variable: yp1 
Berdasarkan tabel 9 dapat diketahui nilai $\mathrm{F}$ hitung sebesar 3,583dengan signifikansi sebesar 0,040. Karena probabilitas lebih kecil dari 0,05 makan dapat disimpulkan bahwa $\mathrm{H}_{\mathrm{o}}$ ditolak dan $\mathrm{H}_{\mathrm{a}}$ diterima. Artinya, Pengetahuan Peraturan Perpajakan dan Kualitas Pelayanan mempunyai pengaruh signifikan terhadap Kepatuhan Wajib Pajak

\section{KESIMPULAN DAN SARAN}

\subsection{Kesimpulan}

Berdasarkan hasil penelitian dan pembahasan mengenai pengaruh Pengetahuan Peraturan Perpajakan dan Kualitas Pelayanan terhadap Kepatuhan Wajib Pajak pada Kantor Pelayanan Pajak (KPP) Pratama BandungKareesdapat ditarik kesimpulan sebagai berikut:

1. Pengetahuan Peraturan Perpajakan pada Kantor Pelayanan Pajak Pratama Bandung Kareessecara umum berada dalam kategori baik. Artinya sudah memenuhi 6 indikator, yaitu Kepemilikan Nomor Pokok Wajib Pajak (NPWP), Pengetahuan dan pemahaman mengenai hak dan kewajiban, Pengetahưan dan pemahaman mengenai sanksi perpajakan, Pengetahuan dan pemahaman mengenai Penghasilan Tidak Kena Pajak (PTKP), Penghasilan Kena Pajak (PKP), dan Tarif Pajak, Mengetahui dan memahami peraturan perpajakan melalui sosialisasi yang dilakukan oleh KPP, Mengetahui dan memahami peraturan pajak melalui training perpajakan yang mereka ikuti.

Kualitas Pelayanan pada KPP Pratama Bandung Karees secara umum berada dalam kategori baik. Artinya sudah memenuhi 5 indikator, yaitu Tangibles, Emphaty, Realibilty, Responsiveness dan Assurance yang masing-masing indikator menunjukkan tingkat tanggapan pada kondisi baik.

Kepatuhan Wajib Pajak pada KPP Pratama Bandung Kareessecara umum berada dalamkategori cukup baik. Artinya sudah memenuhi 4 indikator, yaitu mengisi formulir pajak dengan lengkap dan jelas, menghitung jumlah pajak yang terutang dengan benar, membayar pajak yang terutang tepat pada waktunya, menyampaikan atau melaporkan Surat Pemberitahuan (SPT) tepat pada waktunya yang masing-masing indikator menunjukkan tingkat tanggapan pada kondisi cukup baik.

2. Berdasarkan hasil pengujian hipotesis secara parsial, diketahui bahwa:

a. Pengetahuan Peraturan Perpajakan berpengaruh signifikan terhadap Kepatuhan Wajib Pajakpada KPP Pratama Bandung Karees.

b. Kualitas Pelayanan tidak berpengaruh signifikan terhadap Kepatuhan Wajib Pajakpada KPP Pratama Bandung Karees.

3. Berdasarkan hasil pengujian hipotesis secara simultan diketahui bahwa Pengetahuan Peraturan Perpajakan dan Kualitas Pelayanan berpengaruh signifikan terhadap Kepatuhan Wajib Pajak pada KPP Pratama Bandung Karees.

\subsection{Saran}

Setelah peneliti memberikan kesimpulan dari hasil penelitian tentang Pengetahuan Peraturan Perpajakan dan Kualitas Pelayanan terhadap Kepatuhan Wajib Pajak pada Kantor Pelayanan Pajak (KPP) Pratama BandungKarees, maka peneliti akan memberikan beberapa saran sebagai berikut:

\section{Bagi Wajib Pajak}

Berdasarkan dari hasil tanggapan Account Representative dan pemeriksa pajak mengenai kepatuhan Wajib Pajak, penulis menilai bahwa kepatuhan Wajib Pajak masih rendah di KPP Pratama Bandung Karees. Penulis memberikan saran kepada Wajib Pajak di KPP Pratama Bandung Karees:

a. Wajib pajak mengisi formulir pajak dengan lengkap dan jelas.

b. Menghitung jumlah pajak yang terutang dengan benar.

c. Membayar pajak yang terutang tepat pada waktunya.

d. Menyampaikan atau melaporkan Surat Pemberitahuan (SPT) tepat pada waktunya untuk meningkatkan kepatuhan Wajib Pajak di KPP Pratama Bandung Karees. 


\section{REFERENSI}

Andi, Sri Rizki Utami, Ayu Noorida Soerono (2012),Pengaruh Faktor-Faktor Eksternal terhadap Tingkat Kepatuhan Wajib pajak, Serang: Universitas Sultan Ageng Tirtayasa.

Drs. Saryadi, Yuli Anita Siregar, dan Sari Listyorini (2010), Pengaruh Pelayanan Fiskus dan Pengetahuan Perpajakan terhadap Kepatuhan Wajib Pajak, Semarang: Universitas Diponegoro

Ghozali, Imam. (2011). Aplikasi Analisis Multivariate Dengan Program SPSS 19. Semarang : Badan Penerbit Universitas Diponegoro.

Mardiasmo (2009), Perpajakan Edisi Revisi 2009, Jakarta, Andi.

Narimawati, Umi., (2007). Riset Manajemen Sumber Daya Manusia Aplikasi Contoh dan Perhitungan, Jakarta: Agung Media.

Nur Hidayati, Supriyati (2008), Pengaruh Pengetahuan Pajak dan Persepsi Wajib Pajak terhadap Kepatuhan Wajib Pajak, Surabaya: STIE Perbanas.

Priyatno, Duwi. (2011), SPSS Analisis Statistik Data, Yogyakarta, MediaKom.

Rahayu, Siti Kurnia (2010), Perpajakan Indonesia Konsep \& Aspek Formal, Yogyakarta: Graha Ilmu.

Resmi, Siti (2008), Perpajakan: Teori dan Kasus, Jakarta: Salemba Empat.

Sanusi, Anwar. (2011). Metodologi Penelitian Bisnis. Jakarta: Salemba Empat.

Sedarmayanti., Syarifudin Hidayat. (2011), Metodologi penelitian, Bandung, CV Mandar Maju.

Sekaran, Uma. (2009). Metodoogi Penelitian untuk Bisnis. Jakarta: Salemba Empat.

Sugiyono. (2011). Metodologi Penelitian Kuantitatif, Kualitatif, dan Kombinasi (Mixed Methods). Bandung: Alfabeta.

Sunyoto, Danang (2009). Analisis Regresi dan Uji Hipotesis. Yogyakarta: Medpres.

Undang-Undang Nomor 28 Tahun 2007 Tentang Ketentuan Umum dan Tata Cara Perpajakan.

Undang-Undang Nomor 36 Tahun 2008 Tentang Pajak Penghasilan.

Undang-Undang Nomor 17 Tahun 2000 Tentang Subjek Pajak.

Undang-Undang Nomor 16 Tahun 2000 Tentang Pemeriksaan Pajak.

Zain, Mohammad. (2007), Manajemen Perpajakan, Jakarta, Salemba Empat.

Zulaikha, Harjanti Puspa Arum (2012), Pengaruh Kesadaran Wajib Pajak, Pelayanan Fiskus, dan Sanksi Pajak terhadap Kepatuhan Wajib Pajak Orang Pribadi yang Melakukan Kegiatan Usaha dan Pekerjaan Bebas, Semarang: Universitas Diponegoro.

Internet

https://nasional.kompas.com (diakses 5 Mei 2013)Ditjen.Pajak.Incar.Pelaku.Bisnis.dan.Orang.Kaya

www.nasional.kontan.co.id (diakses pada 7 Mei 2013) https://nasional.kontan.co.id/news/ditjen-pajakkejar-pajak-dari-40-juta-pekerja 